\title{
ANALISIS TINGKAT KEPUASAN TERHADAP KUALITAS PELAYANAN DAN FASILITAS SWALAYAN TOP 100 TEMBESI BATAM
}

\author{
Yan Mahesa Damanik ${ }^{*}$ \\ ${ }^{1}$ Program Studi Teknik Industri, Universitas Putera Batam, \\ Jl. R. Soeprapto, Muka Kuning, Kibing, Batu Aji, Batam, 29434 \\ *e-mail: yanmahesa.bb@gmail.com
}

\begin{abstract}
In order to be able to compete in the domestic or international market, every company is required to be able to provide satisfaction to each of its customers. Satisfaction is an evaluation of the characteristics of a product or service that determines the level of customer satisfaction towards the fulfillment of consumption needs. Improving Service quality is very important in order to improve customer satisfaction, especially for companies engaged in services such as mall top 100, qualitative descriptive research. This type of research is a qualitative descriptive study. Data obtained by distributing questionnaire scale 5 to 100 respondents. The questionnaire was tested for validity by using the Pearson test for the number of $\mathrm{N}=98$ with a significance level of $5 \%$ that is equal to 0.915 , while the reliability test was tested with the Cornbach alpha test. The level of customer satisfaction in Tembesi, Batam's top 100 mall for tangible dimensions is 31.09 or $69.09 \%$. With satisfaction level satisfied. The dimensions of Assurance satisfaction level of Tembesi's top 100 mall customers, Batam of 7.04 or $70.40 \%$ are categorized as satisfied. The empathy dimension for the top 100 Tembesi mall Batam customer satisfaction level of 7 or $70 \%$ is categorized as satisfied. The reliability dimension for the customer satisfaction level of the Tembesi mall top 100, Batam is 6.85 or $86.50 \%$ categorized as satisfied. The dimension of responsiveness for the top 100 Tembesi mall customer satisfaction level in Batam is 10.78 or $71.87 \%$ categorized as satisfied. Overall, the level of customer satisfaction at the Tembesi mall top 100, Batam of 6.85 or $86.50 \%$ was categorized satisfied from the 100 respondents who filled out the questionnaire was 62.76 or $69.73 \%$ could be categorized as satisfied.
\end{abstract}

Keywords: Kepuasan Pelanggan, Service Quality, IPA

\section{Pendahuluan}

Dunia bisnis dewasa ini baik bisnis dalam bidang jasa maupun non jasa berkembang dengan sangat pesat. Perkembangan teknologi juga memberikan kontribusi yang besar dalam menaikkan tingkat persaingan dalam dunia bisnis di dalam pasar domestik terlebih dalam pasar internasional. Untuk dapat bersaing dalam pasar domestik maupun internasional, setiap perusahaan dituntut untuk dapat memberikan kepuasan terhadap setiap pelanggannya. Kepuasan adalah penilaian terhadap ciri sebuah produk atau pun jasa yang menentukan tingkat kesenangan pelanggan terhadap pemenuhan kebutuhan konsumsi (Lovelock \& Wirtz, 2011), oleh karena itu perusahaan harus dapat memberikan produk ataupun pelayanan yang sesuai dengan keinginan pelanggannya.

Kualitas menjadi aspek terpenting dalam menentukan apakah sebuah perusahaan dapat bersaing dalam pasar domestik maupun internasional. Kepuasan Konsumen dapat dibentuk melalui kualitas, pelayanan dan nilai (Lubis \& Andayani, 2018). Kualitas merupakan tingkat ketercapaian karakteristik yang berkaitan untuk memenuhi persyaratan (Tjiptono, Fandy, \& Chandra, 2006). Kualitas pelayanan sangat penting untuk ditingkatkan untuk meningkatkan kepuasan pelanggan khususnya untuk perusahaan yang bergerak dalam bidang pelayanan seperti mall top 100, memperbaiki dan meningkatkan kualitas pelayanan (service quality) merupakan hal yang sangat penting. Dalam meningkatkan kualitas pelayanan (service quality) terdapat 5 aspek yang harus diperhatikan, yaitu aspek tangible, reliability, responsiveness, assurance, dan empathy. Dalam menghadapi era globalisasi dewasa ini yang penuh tantangan dan peluang, sudah menjadi sebuah keharusan bagi perusahaan untuk meningkatkan kualitas produk maupun pelayanannya untuk menciptakan kepuasan pelanggan.

Berdasarkan latar belakang tersebut, peneliti tertarik untuk mengetahui seberapa tinggi tingkat 
kepuasan pelanggan terhadap pelayanan di top 100 dan apa saja aspek-aspek yang perlu diprioritaskan untuk dikembangkan dalam upaya memperoleh kepuasan pelanggan.

\section{Landasan Teori}

\subsection{Service Quality}

Dalam melaksanakan analisis kualitas jasa, dapat dilakukan dengan cara membuat pernyataan jumlah satuan dalam angka dengan menggunakan skala Likert terhadap angket yang disebarkan kepada responden. Pengukuran kualitas jasa dilakukan dengan mengetahui besarnya disparitas terhadap persepsi pelanggan dan harapan pelanggan. Pengkuran ini dilakukan karena kualitas pelayanan dapat diartikan sebagai besarnya perbedaan harapan pelanggan dengan persepsi pelanggan terhadap pelayanan yang diterimanya. Kualitas pelayanan (service quality) pada dasarnya merupakan dugaan yang dilakukan konsumen dalam membandingkan kinerja ataupun kualitas pelayanan yang diterimanya berdasarkan kategori-kategori yang relevan dengan standar kualitas pelayanan ataupun jasa. Perolehan nilai service quality untuk setiap butir pernyataan yang terdapat pada kuesioner dapat dihitung dengan mengurangi nilai perolehan untuk presepsi terhadap nilai perolehan untuk harapan (Tjiptono et al., 2006). Setelah dilakukan perhitungan tersebut, maka akan diperoleh kesenjangan yang merupakan selisih antara persepsi dengan kenyataan. Jika hasil perhitungan memiliki nilai yang lebih besar dari minus 1 ($0,85)$ artinya tingkat service quality terhadap butir atau pun dimensi tersebut dapat dikategorikan baik. Namun sebaliknya jika hasil perhitungan memiliki nilai lebih kecil dari minus $1(-1,50)$, artinya tingkat service quality terhadap butir atau pun dimensi tersebut dapat dikategorikan kurang baik. Untuk dapat mengetahui tingkat kualitas service quality yang telah diberikan, dapat dilakukan dengan membagi nilai perolehan persepsi terhadap harapan seperti rumus berikut:

Quality $=\frac{\text { persepsi }}{\text { harapan }}$

Service quality memiliki lima dimensi penilaian yaitu sebagai berikut (Kasus, Kuningan, Mariska, $\&$ Shihab, 2016):

a. Tangible (berwujud)
Dimensi tangible berkaitan dengan aspek fisik seperti fasilitas, peralatan, sarana, dan lingkungan. Dimensi ini membangun impresi konsumen.

b. Empathy (empati)

Dimensi empathy merupakan kemampuan dalam memberikan perhatian dan memahami keinginan pelanggan. Dimensi ini mencakup aspek accebility dan senstivity dan upaya untuk memenuhi kebutuhan serta keinginan pelanggan.

c. Reliability (keyakinan)

Dimensi reliability merupakan kemampuan dalam memenuhi janji terhadap pelanggan. Dimensi ini menunjukkan kejujuran bukan kebohongan, kemampuann memberikan pelayan secara konsisten. Dimensi ini adalah dimensi utama pembentuk kesan tehadap pelanggan.

d. Responsiveness (respon dan tanggung jawab) Dimensi responsiveness merupakan kemampuan perusahaan dalam melaksanakan tanggung jawab pelayanan yang baik, cepat dan tepat. Dimensi ini menunjukkan kemampuan perusahaan untuk hadir secara sukarela memberikan pelayanan dan perhatian kepada pelanggan.

e. Assurance (Jaminan)

Dimensi assurance berkaitan dengan kemampuan orang (pegawai) dalam melayani konsumen dalam rangka membangun rasa percaya pelanggan terhadap perusahaan.

\subsection{Importance Performance Analysis (IPA)}

Menurut Philip Kotler, IPA dapat digunakan untuk merangking berbagai elemen dari kumpulan jasa dan mengidentifikasi tindakan yang diperlukan. Dalam metode ini diperlukan pengukuran tingkat kesesuaian untuk mengetahui seberapa besar pelanggan merasa puas terhadap kinerja perusahaan, dan seberapa besar pihak penyedia jasa memahami apa yang diinginkan pelanggan terhadap jasa yang mereka berikan. Pada IPA dilakukan pemetaan menjadi 4 kuadran untuk seluruh variabel yang mempengaruhi kualitas pelayanan.

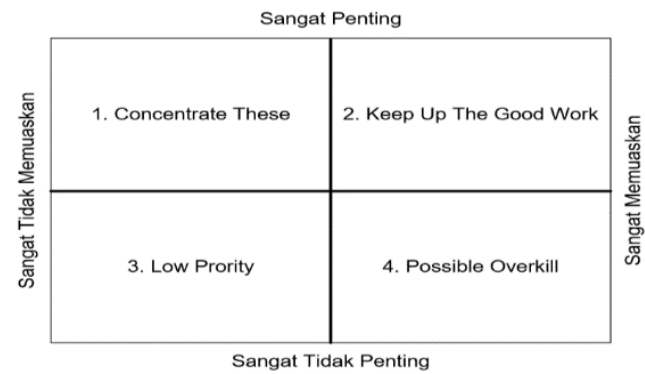

Gambar 1. Peta IPA

Sumber: (Nugraha, Ambar, \& Adianto, 2014) 
Kuadran 1 (Concentrate These) merupakan area terhadap yang memiliki tingkat kepentingan tinggi oleh pelanggan, tetapi memiliki nilai persepsi yang rendah. Artinya area ini memuat faktor yang memiliki harapan tinggi tetapi pada kenyataannya masih rendah (tingkat kepuasan pelanggan masih rendah). Variabel-variabel yang masuk dalam kuadran ini harus ditingkatkan. Kuadran 2 (Keep Up the Good Work) merupakan area terhadap yang memiliki tingkat kepentingan tinggi oleh pelanggan, dan juga memiliki nilai persepsi yang tinggi. Setiap variabel yang masuk ke dalam area ini harus dipertahankan oleh perusahaan karena setiap variabel yang masuk ke area ini merupakan produk ataupun jasa unggulan yang dimiliki oleh perusahaan. Kuadran 3 (Low Priority) merupakan area terhadap yang memiliki tingkat kepentingan rendah oleh pelanggan, tetapi memiliki nilai persepsi yang juga rendah. Setiap variabel yang masuk ke dalam area ini dianggap kurang penting oleh pelanggan. Setiap variabel yang masuk ke dalam area ini peningkatan kualitasnya perlu dipertimbangankan atau tidak seharusnya menjadi prioritas karena manfaatnya terhadap pelanggan juga kecil. Kuadran 4 (Possible Overkill) merupakan area yang memuat faktror-faktor yang dianggap kurang penting oleh pelanggan, dan dirasakan terlalu berlebihan. Setiap variabel yang masuk ke dalam area ini sebaiknya dikurangi untuk mejaga agar perusahaan dapat menghemat biaya (Nugraha et al., 2014).

\section{Metode Penelitian}

Jenis penelitian yang digunakan dalam penelitian ini adalah penelitian deskriptif kualitatif. Populasi penelitian ini adalah pelanggan yang berbelanja di mall Top 100, Tembesi, Batam. Teknik penentuan sampel yang digunakan dalam penelitian ini adalah accidental sampling. Data diperoleh dengan menyebarkan kuesioner skala 5 kepada 100 responden.

Untuk mengetahui tingkat kepuasan pelanggan top 100 terhadap aspek pelayanan yang diberikan, maka nilai perhitungan kuesioner akan konversi dari data kuantitatif menjadi kualitatif dengan tabel 1 berikut:

Tabel 1. Konversi Nilai Aspek Kriteria

\begin{tabular}{cc}
\hline Interval & Kriteria \\
\hline$\overline{\boldsymbol{X}}+\mathbf{1}, \mathbf{5} \boldsymbol{S} \boldsymbol{D}<\boldsymbol{X}$ & Sangat Puas \\
\hline$\overline{\boldsymbol{X}}+\mathbf{0}, \mathbf{5} \boldsymbol{S} \boldsymbol{D}<\boldsymbol{X} \leq \bar{X}+1,5 \mathrm{SD}$ & Puas \\
\hline$\overline{\boldsymbol{X}}-\mathbf{0}, \mathbf{5} \boldsymbol{S} \boldsymbol{D}<\boldsymbol{X} \leq \bar{X}+0,5 \mathrm{SD}$ & Cukup Puas \\
\hline$\overline{\boldsymbol{X}}-\mathbf{1}, \mathbf{5} \boldsymbol{S} \boldsymbol{D}<\boldsymbol{X} \leq \overline{\boldsymbol{X}}+0,5 \mathrm{SD}$ & Tidak Puas \\
\hline $\mathrm{X} \leq \overline{\boldsymbol{X}}-\mathbf{1}, \mathbf{5} \boldsymbol{S D}$ & Sangat Tidak Puas \\
\hline
\end{tabular}

Sumber: Saputra, 2007
Keterangan:

$\bar{X}=$ rerata skor keseluruhan siswa dalam satu kelas

$\mathrm{X}=$ skor yang dicapai siswa

$\mathrm{SD}=$ simpangan baku skor keseluruhan siswa dalam satu kelas

Kuesioner diuji validitasnya dengan menggunakan uji pearson untuk jumlah $\mathrm{N}=98$ dengan taraf signifikansi 5\% yaitu sebesar 0,915, sementara uji realibilitasnya diuji dengan dengan uji cornbach alpha. Untuk dapat mengetahui tinggi rendahnya reliabilitas instrumen digunakan kategori sebagai berikut (Hadi, 2013):

$$
\begin{array}{ll}
0,800-1,000 & \text { : sangat tinggi } \\
0,600-0,799 & \text { : tinggi } \\
0,400-0,599 & : \text { cukup } \\
0,200-0,399 & : \text { rendah } \\
0,000-0,199 & \text { : sangat rendah }
\end{array}
$$

Selain kuesioner, peneliti juga melakukan studi pustaka dengan menghimpun dan menganalisis data sekunder yang relevan dari buku-buku, jurnal, dan sumber-sumber lain yang kredibel.

Data yang diperoleh kemudian diolah dengan menggunakan metode rating scale skala lima dan juga menggunakan metode Importance Performance Analysis.

\section{Hasil dan Pembahasan}

Berdasarkan hasil pengujian validitas, kuesioner yang dibagikan kepada 100 responden berstatus valid, karena $r$ hitung $>r$ tabel. Hasil pengujian validitas dapat dilihat pada tabel 2. di bawah ini:

Tabel 2. Hasil Uji Validitas

\begin{tabular}{cccc}
\hline \multicolumn{4}{c}{ uji validitas } \\
\hline butir & r hitung & r tabel & status \\
\hline 1 & 0,422 & 0,195 & Valid \\
\hline 2 & 0,450 & 0,195 & Valid \\
\hline 3 & 0,543 & 0,195 & Valid \\
\hline 4 & 0,582 & 0,195 & Valid \\
\hline 5 & 0,603 & 0,195 & Valid \\
\hline 6 & 0,586 & 0,195 & Valid \\
\hline 7 & 0,638 & 0,195 & Valid \\
\hline 8 & 0,565 & 0,195 & Valid \\
\hline 9 & 0,640 & 0,195 & Valid \\
\hline 10 & 0,503 & 0,195 & Valid \\
\hline 11 & 0,619 & 0,195 & Valid \\
\hline 12 & 0,653 & 0,195 & Valid \\
\hline 13 & 0,644 & 0,195 & Valid \\
\hline 14 & 0,399 & 0,195 & Valid \\
\hline 15 & 0,588 & 0,195 & Valid \\
\hline 16 & 0,568 & 0,195 & Valid \\
\hline 17 & 0,652 & 0,195 & Valid \\
\hline 18 & 0,667 & 0,195 & Valid \\
\hline
\end{tabular}

Sumber: Pengolahan data (2019) 
Berdasarkan perhitungan reliabilitas untuk uji reliabilitas, diperoleh bahwa kuesioiner yang digunakan adalah reliabel karena $\mathrm{r}$ hitung $>\mathrm{r}$ tabel yaitu 0,876>0,195 dan memiliki reliabilitas yang sangat tinggi karena berada pada interval 0,8 - 1 yaitu sebesar 0,876 . Hasil uji reliabilitas dapat dilihat pada tabel 3 berikut ini:

Tabel 3. Hasil Uji Reliabilitas

\begin{tabular}{cccc}
\hline \multicolumn{4}{c}{ Uji Reliabilitas } \\
\hline r hitung & r tabel & status & kategori \\
\hline 0,876 & 0,195 & Reliabel & Sangat tinggi \\
\hline
\end{tabular}

Sumber: Pengolahan data (2019)

Berdasarkan hasil skor servqual untuk dimensi secara keseluruhan didapatkan hasil data servqual adalah sebagai berikut:

tangible $\quad(-0,776), \quad$ reliability $\quad(-0,945)$, responsiveness ( $-0,790)$ assurance $(-0,800)$, dan empathy yaitu (-0,860), dan berdasarkan perhitungan skor servqual hasil perhitungan gap untuk kelima dimensi yaitu selisih antara kenyataan dan harapan > -1 yang berarti baik, sedangkan untuk kualitas (Q) setiap dimensi adalah tangible 0,817 , reliability 0,784 , responsiveness 0,820 , assurance 0,815 , dan empathy yaitu 0,803. Berdasarkan perhitungan nilai dari kualitas (Q) untuk kelima dimensi yaitu mendekati nilai 1 yang berarti baik.

Tabel 4. Skor Servqual Pelanggan Mall top 100 Tembesi, Batam

\begin{tabular}{ccccc}
\hline \multirow{2}{*}{ Dimensi } & \multicolumn{2}{c}{ Rata-rata } & & \\
\cline { 2 - 3 } & Persepsi & $\begin{array}{c}\text { Hara } \\
\text { pan }\end{array}$ & GAP & Q=P/H \\
\hline Tangible & 3,454 & 4,230 & $-0,776$ & 0,817 \\
Assurance & 3,520 & 4,320 & $-0,800$ & 0,815 \\
$\begin{array}{c}\text { Empathy } \\
\text { Reliability }\end{array}$ & 3,500 & 4,360 & $-0,860$ & 0,803 \\
$\begin{array}{c}\text { Responsiven } \\
\text { ess }\end{array}$ & 3,425 & 4,370 & $-0,945$ & 0,784 \\
\hline Sumbernnnnnn & 3,593 & 4,383 & $-0,790$ & 0,820 \\
\hline
\end{tabular}

Sumber: Pengolahan data (2019)

Berdasarkan tabel 4. Penilaian untuk keseluruhan dimensi diperoleh skor ideal sebesar 69,73 atau $62,73 \%$ dari 18 butir penilaian. Simpangan baku ideal yang diperoleh adalah 12 . Jika perolehan data tersebut disesuaikan dengan skala kategori kepuasan dapat disimpulkan bahwa tingkat kepuasan pelanggan mall Top 100 Tembesi, Batam masuk ke dalam kategori puas karena berada pada interval $60<\mathrm{X} \leq 72$.
Tabel 4. Tingkat Kepuasan Pelanggan Mall Top 100 Tembesi, Batam

\begin{tabular}{cc}
\hline Interval & Kriteria \\
\hline $\mathbf{7 2} \leq \mathbf{X} \leq \mathbf{9 0}$ & Sangat Puas \\
\hline $\mathbf{6 0} \leq \mathbf{X} \leq \mathbf{7 2}$ & Puas \\
\hline $\mathbf{4 8} \leq \mathbf{X} \leq \mathbf{6 0}$ & Cukup Puas \\
\hline $\mathbf{3 6} \leq \mathbf{X} \leq \mathbf{4 8}$ & Tidak Puas \\
\hline $\mathbf{1 8} \leq \mathbf{X} \leq \mathbf{3 6}$ & Sangat Tidak Puas \\
\hline Sumber: Pengolahan data (2019)
\end{tabular}

Berdasarkan tabel 5. Penilaian untuk dimensi tangible oleh pengunjung mall Top 100 Tembesi, Batam memperoleh skor ideal sebesar 31,09 atau $69,09 \%$ dari 9 butir penilaian. sementara simpangan baku ideal yang diperoleh adalah 6 . Jika perolehan data tersebut disesuaikan dengan skala kategori kepuasan dimensi tangible dapat disimpulkan bahwa tingkat kepuasan pelanggan mall Top 100 Tembesi, Batam masuk ke dalam kategori puas karena berada pada interval $30<\mathrm{X}$ $\leq 36$.

Tabel 5. Tingkat Kepuasan Pelanggan dimensi tangible Mall Top 100 Tembesi, Batam

\begin{tabular}{cc}
\hline Interval & Kriteria \\
\hline $\mathbf{3 6} \leq \mathbf{X} \leq \mathbf{4 5}$ & Sangat Puas \\
$\mathbf{3 0} \leq \mathbf{X} \leq \mathbf{3 6}$ & Puas \\
\hline $\mathbf{2 4} \leq \mathbf{X} \leq \mathbf{3 0}$ & Cukup Puas \\
\hline $\mathbf{1 8} \leq \mathbf{X} \leq \mathbf{2 4}$ & Tidak Puas \\
\hline $\mathbf{1 1} \leq \mathbf{X} \leq \mathbf{1 8}$ & Sangat Tidak Puas \\
\hline
\end{tabular}

Sumber: Pengolahan data (2019)

Pada tabel 6. Penilaian untuk dimensi assurance oleh pengunjung mall Top 100 Tembesi, Batam memproleh skor sebesar 7,04 atau 70,40\% dari 2 butir penilaian. simpangan baku ideal yang diperoleh untuk penilaian yaitu 1,33. Jika perolehan data tersebut disesuaikan dengan skala kategori kepuasan dimensi assurance dapat disimpulkan bahwa tingkat kepuasan pelanggan mall Top 100 Tembesi, Batam masuk ke dalam kategori puas karena berada pada interval 6,67 < $\mathrm{X} \leq 8$.

Tabel 6. Tingkat Kepuasan Pelanggan dimensi assurance Mall Top 100 Tembesi, Batam

\begin{tabular}{|c|c|}
\hline Interval & Kriteria \\
\hline $8 \leq X \leq 10$ & Sangat Puas \\
\hline $6,67 \leq X \leq 8$ & Puas \\
\hline $5,33 \leq X \leq 6,67$ & Cukup Puas \\
\hline $4 \leq X \leq 5,33$ & Tidak Puas \\
\hline $2 \leq X \leq 4$ & Sangat Tidak Puas \\
\hline
\end{tabular}

Pada tabel 7. Penilaian untuk dimensi empathy oleh pengunjung mall Top 100 Tembesi, Batam 
memproleh skor sebesar 7 atau $70 \%$ dari 2 butir penilaian. simpangan baku ideal yang diperoleh untuk penilaian yaitu 1,33 . Jika perolehan data tersebut disesuaikan dengan skala kategori kepuasan dimensi empathy dapat disimpulkan bahwa tingkat kepuasan pelanggan mall Top 100 Tembesi, Batam masuk ke dalam kategori puas karena berada pada interval $6,67<\mathrm{X} \leq 8$.

Tabel 7. Tingkat Kepuasan Pelanggan dimensi empathy Mall Top 100 Tembesi, Batam

\begin{tabular}{|c|c|}
\hline Interval & Kriteria \\
\hline $8 \leq X \leq 10$ & Sangat Puas \\
\hline $6,67 \leq X \leq 8$ & Puas \\
\hline $5,33 \leq X \leq 6,67$ & Cukup Puas \\
\hline $4 \leq X \leq 5,33$ & Tidak Puas \\
\hline $2 \leq X \leq 4$ & Sangat Tidak Puas \\
\hline
\end{tabular}

Berdasarkan tabel 8. Penilaian untuk dimensi reliability oleh pengunjung mall Top 100 Tembesi, Batam memperoleh skor ideal sebesar 6,85 atau $68,50 \%$ dari 2 butir penilaian. sementara simpangan baku ideal yang diperoleh adalah 1,33. Jika perolehan data tersebut disesuaikan dengan skala kategori kepuasan dimensi reliability dapat disimpulkan bahwa tingkat kepuasan pelanggan mall Top 100 Tembesi, Batam masuk ke dalam kategori puas karena berada pada interval $6,67<\mathrm{X} \leq 8$.

Tabel 8. Tingkat Kepuasan Pelanggan dimensi reliability Mall Top 100 Tembesi, Batam

\begin{tabular}{|c|c|}
\hline Interval & Kriteria \\
\hline $8 \leq X \leq 10$ & Sangat Puas \\
\hline $6,67 \leq X \leq 8$ & Puas \\
\hline $5,33 \leq X \leq 6,67$ & Cukup Puas \\
\hline $4 \leq X \leq 5,33$ & Tidak Puas \\
\hline $2 \leq X \leq 4$ & Sangat Tidak Puas \\
\hline
\end{tabular}

Berdasarkan tabel 9. Penilaian untuk dimensi responsiveness oleh pengunjung mall Top 100 Tembesi, Batam memperoleh skor ideal sebesar 10,78 atau $71,78 \%$ dari 3 butir penilaian. sementara simpangan baku ideal yang diperoleh adalah 2. Jika perolehan data tersebut disesuaikan dengan skala kategori kepuasan dimensi responsiveness dapat disimpulkan bahwa tingkat kepuasan pelanggan mall Top 100 Tembesi, Batam masuk ke dalam kategori puas karena berada pada interval $10<\mathrm{X} \leq 12$.
Tabel 9. Tingkat Kepuasan Pelanggan dimensi responsiveness Mall Top 100 Tembesi, Batam

\begin{tabular}{lc}
\hline Interval & Kriteria \\
\hline $12 \leq \mathrm{X} \leq 15$ & Sangat Puas \\
\hline $10 \leq \mathrm{X} \leq 12$ & Puas \\
\hline $8 \leq \mathrm{X} \leq 10$ & Cukup Puas \\
\hline $6 \leq \mathrm{X} \leq 8$ & Tidak Puas \\
\hline $3 \leq \mathrm{X} \leq 6$ & Sangat Tidak Puas \\
\hline \multicolumn{2}{l}{ Sumber: Pengolahan data (2019) }
\end{tabular}

Berdasarkan diagram IPA pada gambar 2, maka faktor-faktor yang berkaitan dengan pelayanan mall Top 100 dapat dikelompokkan dalam masing-masing kuadran berikut:

a. Kuadran I: Tingkatkan Kinerja

1) Kesopanan dan keramahan pegawai swalayan dalam melayani pelanggan (butir 10)

2) Kejelasan pegawai dalam menjawab pertanyaan pelanggan (butir 11)

3) Kesigapan kasir dalam melayani pelanggan (butir 13)

Faktor-faktor yang terletak pada kudran ini dianggap sebagai faktor yang sangat penting namun kondisi pada saat ini belum memuaskan bagi pelanggan mall top 100 .

b. Kuadran II: Pertahankan Kinerja

1) Pencahayaan di dalam bangunan baik (butir 5)

2) Produk-produk yang dijual disusun berdasarkan raknya masing-masing (butir 6)

3) Jumlah troli belanjaan disediakan cukup banyak (butir 9)

4) Transaksi tersedia dalam bentuk tunai, debet, maupun kredit (butir 14)

5) Mekanisme transaksi di swalayan cukup jelas (butir 15)

6) Perasaan nyaman selama berbelanja di swalayan (butir 18)

Faktor-faktor yang terletak pada kuadran ini dianggap sebagai faktor penunjang bagi kepuasan pelanggan mall top 100. Pihak pengelola mall top 100 berkewajiban mempertahankan prestasi yang telah dicapai.

c. Kuadran III: Prioritas Rendah

1) Terdapat tempat penitipan barang di pintu masuk swalayan (butir 3)

2) Rak penyimpanan disusun berdasarkan raknya masing-masing (butir 4) 
3) Disediakan plakat penunjuk arah di dalam swalayan (butir 7)

4) Terdapat scanner barcode untuk mengecek harga barang secara mandiri (butir 8)

5) Pegawai swalayan cepat tanggap dalam menghadapi keluhan pelanggan (butir 12)

6) Discount produk yang ditawarkan sesuai dengan yang dipromosikan (butir 16)

7) Pegawai swalayan dapat menjelaskan secara jelas setiap pertanyaan pelanggan baik mengenai produk ataupun promosi yang ditawarkan (butir 17)
Faktor-faktor yang terletak pada kuadran ini dinilai kurang penting oleh pelanggan mall top 100 akan tetapi telah dilakukan dengan baik oleh pengelola mall top 100 .

d. Kuadran IV: Cenderung Berlebihan

Tempat parkir disediakan di tempat yang mudah untuk dijangkau (butir 1).

Faktor-faktor yang terletak pada kuadran ini dianggap sudah sangat memuaskan namun tidak terlalu penting bagi pelanggan mall top 100. Pihak pengelola tidak perlu terlalu banyak mengalokasikan sumber daya untuk aspek tersebut, cukup dengan mempertahankan dan menyesuaikan dengan kondisi saat ini.

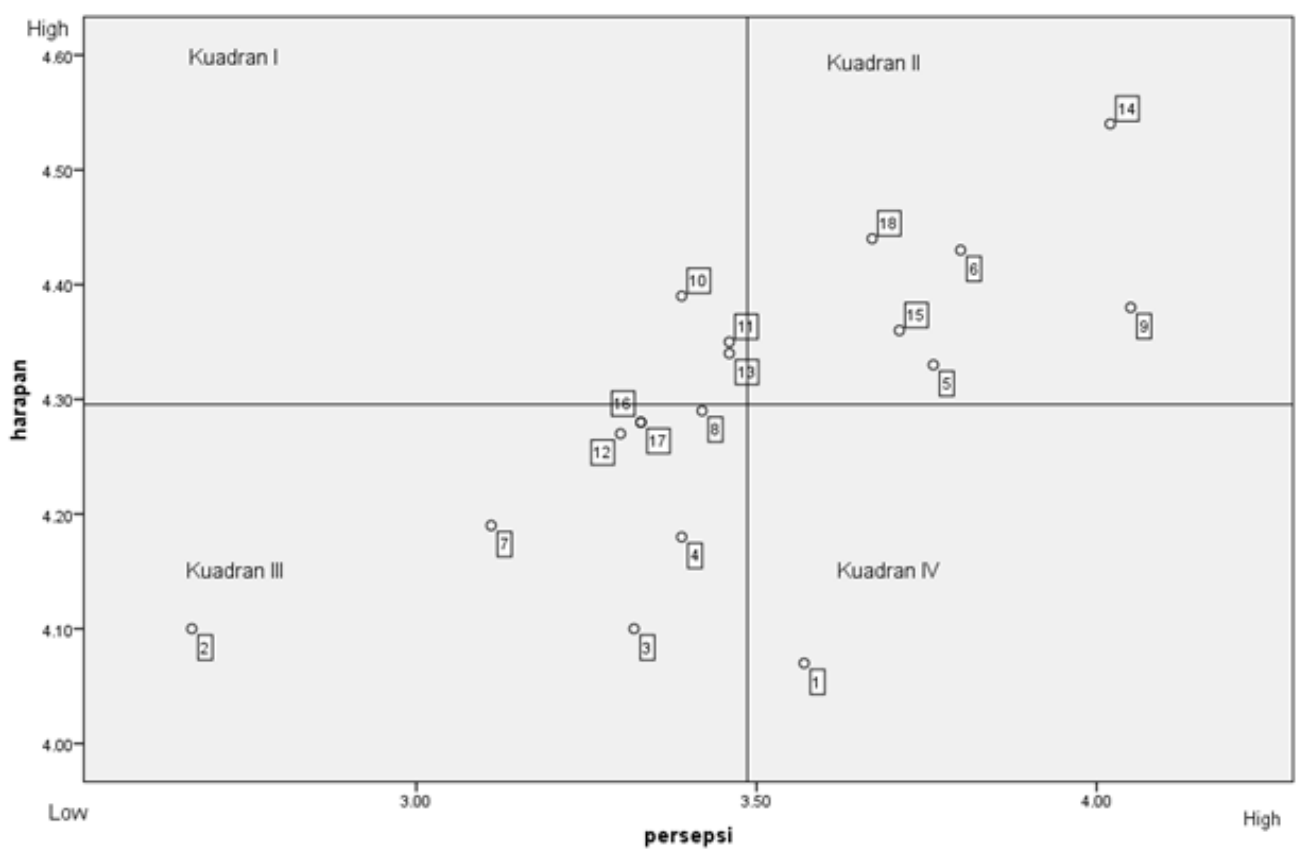

Gambar 2. Diagram IPA mall Top 100

\section{Kesimpulan}

Tingkat kepuasan pelanggan mall top 100 Tembesi, Batam terhadap dimensi tangible adalah sebesar 31,09 atau 69,09\%. Dengan tingkat kepuasan puas. Dimensi Assurance tingkat kepuasaan pelanggan mall top 100 Tembesi, Batam sebesar 7,04 atau 70,40\% dikategorikan puas. Dimensi empathy untuk tingkat kepuasan pelanggan mall top 100 Tembesi, Batam sebesar 7 atau $70 \%$ dikategorikan puas. Dimensi reliability untuk tingkat kepuasan pelanggan mall top 100 Tembesi, Batam sebesar 6,85 atau 86,50 \% dikategorikan puas. Dimensi responsiveness untuk tingkat kepuasan pelanggan mall top 100 Tembesi, Batam sebesar 10,78 atau 71,87\% dikategorikan puas.

Secara keseluruhan tingkat kepuasan pelanggan mall top 100 Tembesi, Batam sebesar 6,85 atau 86,50\% dikategorikan puas dari 100 responden yang mengisi kuesioner adalah 62,76 atau $69,73 \%$ dapat dikategorikan puas. Adapun aspek yang perlu menjadi prioritas utama pihak pengelola mall top 100 untuk dikembangkan adalah aspek kesopanan dan keramahan pegawai swalayan dalam melayani pelanggan, kejelasan pegawai dalam menjawab pertanyaan pelanggan, kesigapan kasir dalam melayani pelanggan. 


\section{Daftar Referensi}

Hadi, S. (2013). Statistik Jilid 2. Yogyakarta: Yayasan Penerbitan Fak.Psikologi UGM.

Kasus, S., Kuningan, A., Mariska, Z. H., \& Shihab, M. S. (2016). Pengaruh Dimensi Service Quality Terhadap Kepuasan Tamu Hotel Dan Dampaknya Terhadap Behaviour Intention (Studi Kasus pada Hotel Aston Kuningan Suites-Jakarta). Jurnal Manajemen Dan Bisnis Sriwijaya, 14(2), 217-234.

Lovelock, C., \& Wirtz, J. (2011). Pemasaran Jasa Perspektif edisi 7. Jakarta: Erlangga.

Lubis, A. S., \& Andayani, N. R. (2018). Pengaruh Kualitas Pelayanan (Service Quality) Terhadap Kepuasan Pelanggan Pt. Sucofindo Batam. Journal of Applied Business Administration, 1(2), 232-243. https://doi.org/10.30871/jaba.v1i2.619

Nugraha, R., Ambar, H., \& Adianto, H. (2014). UsulanPeningkatan Kualitas Pelayanan Jasa pada Bengkel "X" Berdasarkan Hasil Matrix Importance-Performance Analysis (Studi kasus di Bengkel AHASS PD. Sumber Motor Karawang). Jurnal Online Institut Teknologi Nasional, 1(3), 221-231. https://doi.org/2338-5081

Tjiptono, Fandy, \& Chandra, G. (2006). Service, Quality, \& Satisfaction. Jakarta: Andi. 